\title{
Upaya Edukasi Sosial Pencegahan Covid-19 Melalui KKN Mahasiswa STIT Rakeyan Santang Karawang
}

\author{
Candra Mochamad Surya1, Yogha Zulvian Iskandar ${ }^{2}$, Herdian Kertayasa $^{3}$, Vina Febiani Musyadad ${ }^{4}$, \\ Chika Gianistika5 ${ }^{5}$, Rini Novianti Yusuf ${ }^{6}$, Sony Kuswandi ${ }^{7}$, Popi Diana Puspitasari ${ }^{8}$ \\ 1,2,6,8 Program Studi Pendidikan Islam Anak Usia Dini, STIT Rakeyan Santang Karawang, Indonesia \\ 3,4,5,7 Program Studi Pendidikan Guru Madrasah Ibtidaiyah, STIT Rakeyan Santang Karawang, Indonesia \\ *e-mail: : candra.surya112@gmail.com ${ }^{1}$, zulvianyogha@gmail.com ${ }^{2}$, herdianhaz@gmail.com ${ }^{3}$, \\ vinamusyadad@gmail.com ${ }^{4}$, cgianistika@gmail.com ${ }^{5}$, rininovi48@gmail.com ${ }^{6}$, \\ sony.kuswandi@ymail.com ${ }^{7}$,popidianaps@gmail.com ${ }^{8}$
}

\begin{abstract}
Abstrak
Program Kuliah Kerja Nyata (KKN) merupakan bentuk implementasi kegiatan pengabdian pada masyarakat (PPM) dalam rangka perwujudan Tri Dharma Perguruan Tinggi. COVID-19 sejak ditemukan menyebar secara luas hingga mengakibatkan pandemi global yang berlangsung sampai saat ini. Pandemi global yang terjadi pula di Indonesia membuat banyak pihak berupaya ikut berperan serta dalam mengatasi. Salah satu bentuk pengabdian nyata adalah kegiatan KKN-PPM STIT Rakeyan Santang Karawang dengan tujuan memberikan edukasi sosial kepada masyarakat khususnya Desa Kalisari Kecamatan Telagasari Kabupaten Karawang. Metode pelaksanaan progam KKN-PPM ini dengan sosialiasi, pelatihan-pelatihan, dan pengelolaan hidup sehat dan dinamis. Hasil kegiatan menunjukkan banyak hal yang dilakukan mulai dari pemberian alat kebersihan dan ibadah, kerja bakti sosial tempat (mushola, madrasah, lapangan), pemasangan pelang batas desa, senam sehat edukasi covid-19, pembekelan usaha ekonomi kreatif, dan edukasi pencegahan covid-19. Kegiatan KKN-PPM STIT Rakeyan Santang Karawang ini dapat meningkatkan kesadaran dan kepedulian masyarakat Desa Kalisari akan pentingnya hidup bersosial kemasyarakatan, sehat, dinamis dan berkemajuan.
\end{abstract}

Kata kunci: Edukasi Sosial, Kepedulian Kemasyarakatan, Pencegahan Covid-19

\begin{abstract}
The Real Community Service Program (KKN) is a form of implementation of community service activities (PPM) in the context of the realization of the Tri Dharma of Higher Education. COVID-19 has since been found to have spread widely, resulting in a global pandemic that has continued to this day. The global pandemic that also occurred in Indonesia made many parties try to participate in overcoming this. One form of real dedication is the KKN-PPM STIT Rakeyan Santang Karawang activity with the aim of providing social education to the community, especially Kalisari Village, Telagasari District, Karawang Regency. The method of implementing the KKN-PPM program includes socialization, training, and management of a healthy and dynamic life. The results of the activities show that many things have been done, starting from providing cleaning and worship tools, social service work for places (prayer rooms, madrasah, fields), installing village borders, training in healthy education for covid-19, training for creative economy businesses, and education on the prevention of covid-19. This KKN PPM STIT Rakeyan Santang Karawang activity can increase awareness and concern for the people of Kalisari Village about the importance of social, healthy, dynamic and progressive life.
\end{abstract}

Keywords: Social Education, Covid-19 Prevention, Community Concern

\section{PENDAHULUAN}

Tridharma adalah kewajiban Perguruan Tinggi untuk menyelenggarakan Pendidikan, Penelitian, dan Pengabdian Kepada Masyarakat [1]. Pendidikan adalah usaha sadar dan terencana untuk mewujudkan suasana belajar dan proses pembelajaran agar peserta didik secara aktif mengembangkan potensi dirinya untuk memiliki kekuatan spiritual keagamaan, pengendalian diri, kepribadian, kecerdasan, akhlak mulia, serta ketrampilan yang diperlukan dirinya, Masyarakat, Bangsa dan Negara [2] 
Menurut Direktorat Riset dan Pengabdian Masyarakat Universitas Indonesia pengabdian kepada masyarakat atau kegaitan pengabdian kepada masyarakat adalah kegiatan yang mencakup upaya-upaya peningkatan kualitas sumber daya manusia antara lain dalam hal perluasan wawasan, pengetahuan maupun peningkatan keterampilan yang dilakukan oleh civas akademika sebagai perwujudan dharma bakti serta wujud kepedulian untuk berperan katif meningkatkan kesejahteraan dan memberdayakan masyarakat luas terlebih bagi masyarakat ekonomi lemah [3]

Pendidikan dan pengabdian tidak bisa dipisahkan, karena dalam impelementasinya pendidikan menjadi wadah di dalam pengembangan ilmu pengetahuan serta kemanusiaan. Oleh karena itu Sekolah Tinggi Ilmu Tarbiyah (STIT) Rakeyan Santang Karawang di dalam eksistensinya berkomitmen menjungjung tinggi pelaksanaan Tridharma Perguruan Tinggi, dengan melaksanakan program KKN tahun 2020 sebagai upaya wujud kepedulian sosial. Kegiatan KKN STIT Rakeyan Santang Karawang tahun 2020 dilaksanakan di Desa Kalisari Kecamatan Telagasari Kabupaten Karawang.

Dalam pelaksanaannya Kegiatan KKN STIT Rakeyan Santang mendukung dan menguatkan program penanggulangan dan pencegahan Covid-19 yang dilakukan Pemerintah Pusat dan Pemerintah Daerah serta Meningkatkan kepedulian Civitas Akademika STIT Rakeyan Santang dalam percepatan pencegahan penularan pandemi Covid-19. Hal ini sesuai dengan Keputusan Presiden Republik Indonesia [4] Tentang Gugus Tugas Percepatan Penanganan Corona Virus Disease 2019 (Covid-19).

Berdasarkan observasi awal lokasi, masih terdapat masyarakat yang kurang memperhatikan protokol kesehatan dan acuh dalam bersosial kemasyarakatan seperti kurangnya kesadaran memakai masker dan belum terbiasa mencuci tangan dalam aktivitas, kurangnya kepedulian terhadap kebersihan tempat ibadah maupun lembaga pendidikan, tidak ditemukannya batas penghubung desa, minimnya kreasi masyarakat dalam pengembangan ekonomi, dan kurangnya kepekaan dalam melakukan kerja bakti sosial kemasyarakatan. Maka dari itu tujuan dilaksanakan kegiatan KKN STIT Rakeyan Santang ini untuk mengedukasi masyarakat Desa Kalisari tentang bahaya dan cara pencegahannya Covid-19 serta kesadaran sosial dengan program dan pelatihan-pelatihan sebagai implementasi pengabdian masyarakat melaui kegiatan KKN STIT Rakeyan Santang Karawang di masa pandemi Covid-19.

Dengan demikian pelaksanaan Kuliah Kerja Nyata (KKN) mahasiswa STIT Rakeyan Santang sangat dibutuhkan mengingat peran kampus sebagai pengembang ilmu dan implementasi di lapangan masyarakat sehingga kegiatan ini diharapkan dapat terwujud dengan baik sebagai bentuk pengabdian dalam mengedukasi masyarakat Desa Kalisari.

\section{METODE}

\section{a. Sasaran}

Dalam mengembangkan pengetahuan yang objektif mengenai gejala-gelaja kemasyarakatan yang dapat dimanfaatkan secara efektif untuk memecahkan masalah sosial [5], maka kegiatan KKN STIT Rakeyan Santang Karawang Tahun 2020, mempunyai tiga kelompok sasaran yaitu mahasiswa, masyarakat bersama Pemerintah Daerah dan Kampus, dengan mendapatkan manfaat dari sasaran tersebut yaitu: a) bagi mahasiswa Memberikan Pengalaman langsung untuk memberikan konsep-konsep ilmu pengetahuan yang telah diperoleh selama menempuh Pendidikan di STIT Rakeyan Santang Karawang, b) menemukan dan menerapkan konsep ilmiah yang telah dimilikinya secara komprehensif, c) melibatkan diri secara langsung dalam proses pembangunan manusia, d) menjalin kerjasama dengan pihak-pihak yang terkait secara serasi, selaras dan sejalan. Bagi Masyarakat dan Pemerintah Daerah a) membantu Masyarakat dan Pemerintah Daerah dalam pelaksanaan pembanguanan terutama dalam bidang Pendidikan, persekolahan, dan sosial kemasyarakatan, terutama bersama menggulangi covid-19, b) meningkatkan kesadaran Masyarakat untuk aktif dalam pembangunan Desa, c) membantu Masyarakat dan Pemerintah Daerah (Pemda) 
dalam mengembangkan kemampuan kader-kader penerus pembangunan Desa. Bagi STIT Rakeyan Santang Karawang a) Mewujudkan fungsi Tri Dharma Perguruan Tinggi secara terpadu, selaras dan seimbang dengan kebutuhan Masyarakat, b) mendapatkan umpan balik dari masyarakat guna memperbaiki kurikulum yang sesuai dengan kebutuhan Masyarakat, c) memantapkan program KKN-PPM sebagai sarana belajar praktis yang efektif dan efisien.

\section{b. Lokasi Kegiatan}

Wilayah pelaksanaan kegiatan KKN tahun 2020 Sekolah Tinggi Ilmu Tarbiyah (STIT) Rakeyan Santang Karawang, berlokasi di Desa Kalisari, Kecamatan Telagasari Kabupaten Karawang.

Secara geografis Desa Kalisari adalah salah satu Desa yang termasuk ke dalam Kecamatan Telagasari dengan Ketinggian \pm 12 MDPL (Meter Di atas Permukaan Laut) dengan suhu rata-rata maksimum $32^{\circ}$ celcius dan minimum $27^{\circ}$ celcius. Desa Kalisari memiliki luas Wilayah $3,2 \mathrm{~km}^{2}$ atau setara 3.200 ha. Sebanyak Kepala Keluarga : 1.471 KK dari jumlah penduduk : 4.629 Jiwa. Desa Kalisari memiliki potensi sumber daya alam yang potensial terutama dalam pertanian. Karena mayoritas masyarakat Desa adalah berpenghasilan dari hasil tani dan hasil perkebunan [6].

\section{c. Metode Pelaksanaan}

Pelaksanaan kegiatan ini dilaksanakan untuk mendapatkan ketercapaian dari tujuan KKN mahasiswa STIT Rakeyan Santang Karawang. Sebelum mahasiswa diberangkatkan ke Desa sasaran yakni Desa Kalisari terlebih dahulu mahasiswa diberi bekal pengetahuan dasar life skill, dan bersosialisasi dalam masyarakat. Sehingga ketika sudah berada di tengah-tengah masyarakat mahasiswa dengan mudah mentransfer ilmu yang telah didapatkan. Adapun tahapan pelaksanaannya adalah:

a) Sosialisasi program KKN guna menumbuhkan rasa solidaritas gotong royong antar warga, dikarenakan masyarakat sekitar sudah mulai tidak memperhatikan kebersihan lingkungan;

b) Sosialisasi dan pemberian edukasi tentang pencegahan Covid-19;

c) Pelatihan kegiatan kesehatan dan kegiatan kebugaran tubuh untuk masyarakat hidup sehat;

d) Diperlukan adanya ide-ide atau gagasan yang dapat memberikan perubahan peningkatan pada perekonomian masyarakat [7]. Pelatihan terhadap ibu-ibu rumah tangga dengan kegiatan usaha ekonomi kreatif untuk meningkatkan perekonomian masyarakat;

e) Pengelolaan lingkungan hidup adanya kelestarian keseimbangan lingkungan, daya dukung lingkungan, daya lenting, ruang lingkup pengelolaan lingkungan, serta citra lingkungan [8]. Maka dari itu perlu partisipasi dalam kegiatan kebersihan fasilitas umum (madrasah, mushola dan lapangan umum);

f) Pembuatan dan pemasangan plang petunjuk arah dan batas wilayah Desa.

g) Pendistribusian alat peraga edukasi, alat kebersihan, dan alat tulis kantor (ATK) bagi sekolah tertinggal.

\section{HASIL DAN PEMBAHASAN}

Pelaksanaan KKN-PPM STIT Rakeyan Santang disesuaikan dengan jadwal yang telah disusun sebelumnya dengan melalui tahapan-tahapan sebagai berikut:

\section{a. Persiapan dan Pembekalan}

Setelah melakukan observasi awal, maka kami mulai mensosialisasikan program yang ingin dilaksanakan dengan melakukan seminar kegiatan di Kantor Desa Kalisari Kecamatan Telagasari dan mengundang lapisan masyarakat serta tokoh masyarakat setempat. Diharapkan dengan adanya sosialisasi ini, masyarakat setempat mengetahui program-program yang akan 
dilaksanakan oleh KKN STIT Rakeyan Santang Karawang Tahun 2020 terkhususnya di wilayah Desa Kalisari.

\section{b. Pelaksanaan}

Pelaksanaan Program KKN mahaiswa yang telah dilaksanakan oleh 27 mahasiswa bersama Dosen Pembimbing Lapangan (DPL) dan masyarakat sebagai sasaran program yang tergabung di dalam kelompok 1 Desa Kalisari, Kecamatan Telagasari, Kabupaten Karawang. Program KKN ini difasilitasi oleh institusi STIT Rakeyan Santang Karawang melalui dana program pengabdian sebesar Rp 9,070,000. Sehingga, dengan bantuan dana tersebut, maka dapat dilaksanakan kegiatan pengabdian yang telah direncanakan. Adapun kegiatan yang berhasil dilaksanakan dapat dilihat dalam dokumentasi berikut:

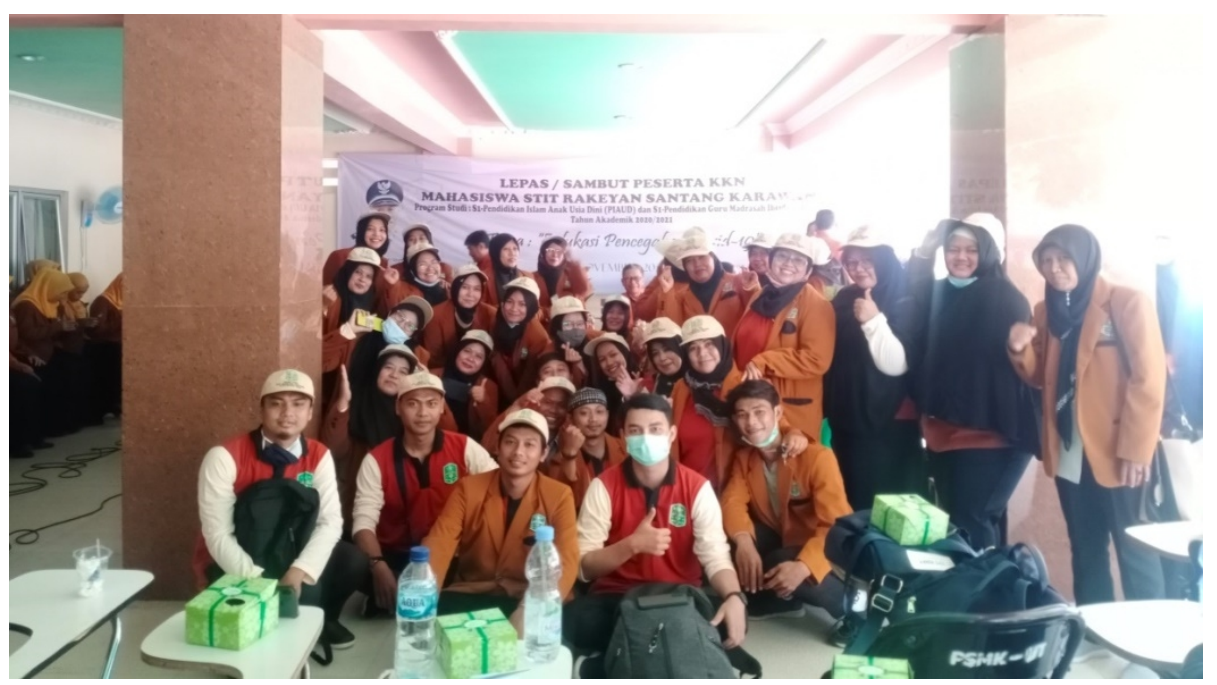

Gambar 1. Sosialiasi dan pelepasan mahasiswa peserta KKN-PPM STIT Rakeyan Santang Karawang

Sebagai wujud Tridharma Perguruan Tinggi STIT Rakeyan Santang berkomitmen dengan melaksanakan pengabdian masyarakat melalui program-program KKN mahasiswa dan diharapkan membantu masyarakat Desa Kalisari menjaga kesehatan dan ikut peduli terhadap sosial kemasyarakatan.

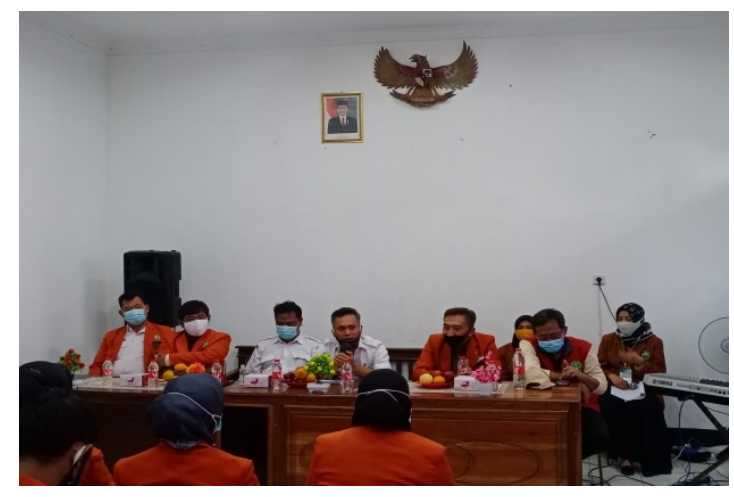

(a)

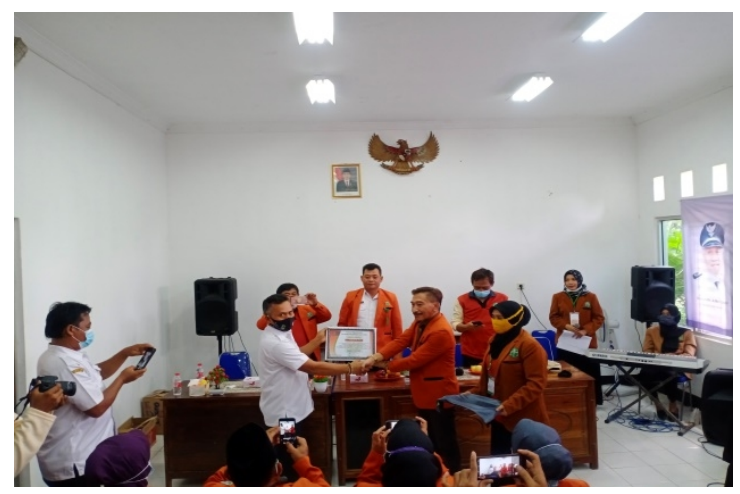

(b)

Gambar 2. Lepas sambut (a) penerimaan mahasiswa KKN oleh Kepala Desa Kalisari (b) penyerahan simbolis oleh Ketua STIT Rakeyan Santang Karawang

Dalam hal ini mahasiswa peserta KKN disambut baik oleh Kepala Desa dan unsur masyarakat dengan harapan dapat bekerjasama dan mengunakan waktu untuk produktif dalam pengembangan masyarakat Desa Kalisari. 


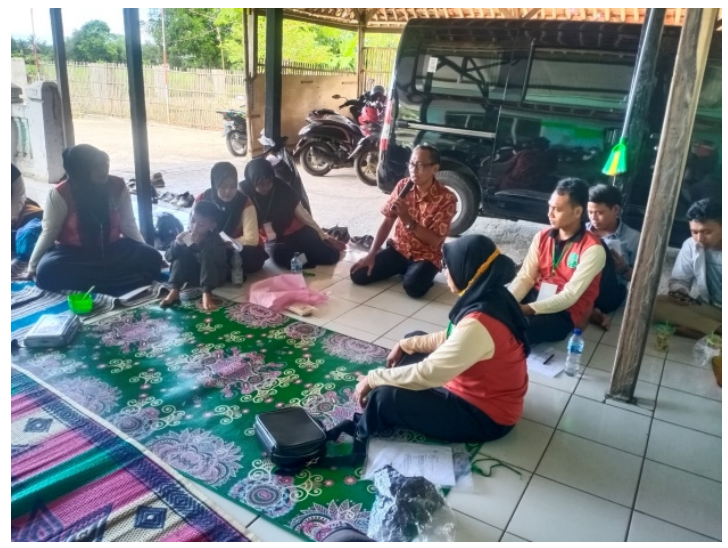

(a)

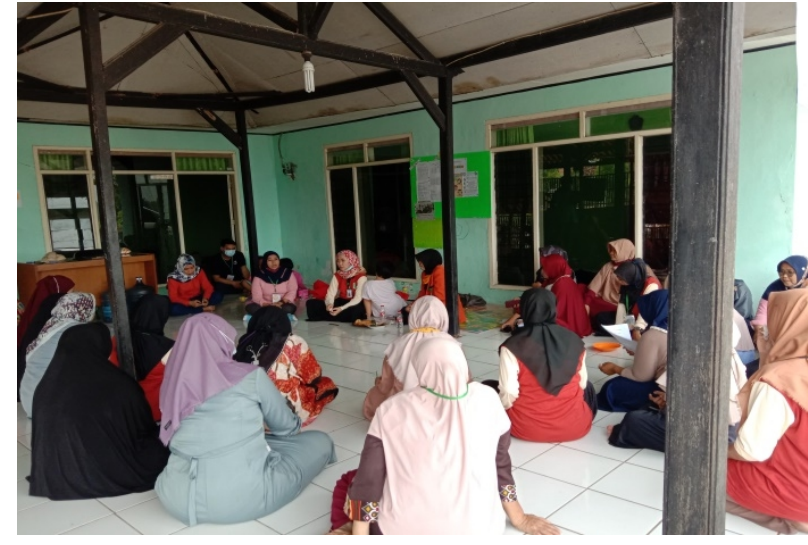

(b)

Gambar 3. Pengarahan program KKN (a) DPL memberikan arahan terhadap peserta KKN (b) peserta KKN STIT Rakeyan Santang antusias mengikuti arahan para DPL

Dalam kegiatan KKN perlu hadirnya Pembimbing Lapangan agar setiap programprogram KKN yang dilaksanakan dapat tercapai sehingga memberikan hasil positif dan kesulitan-kesulitan yang dihadapi di lapangan dapat terselesaikan dengan baik.

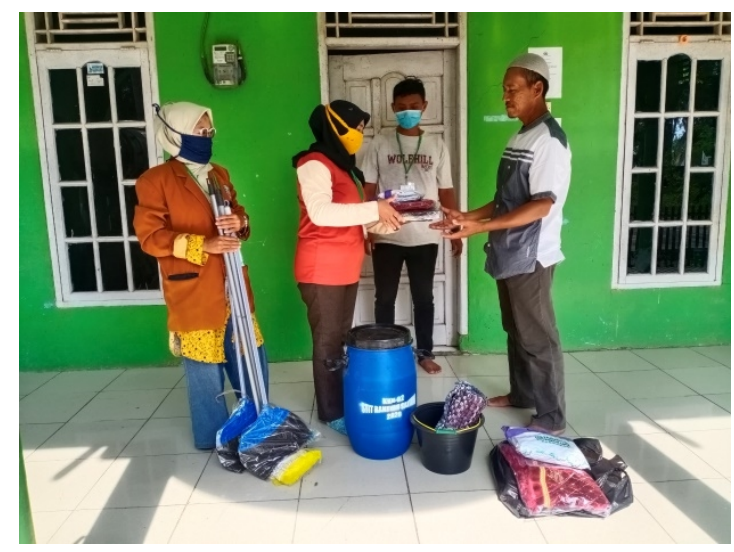

(a)

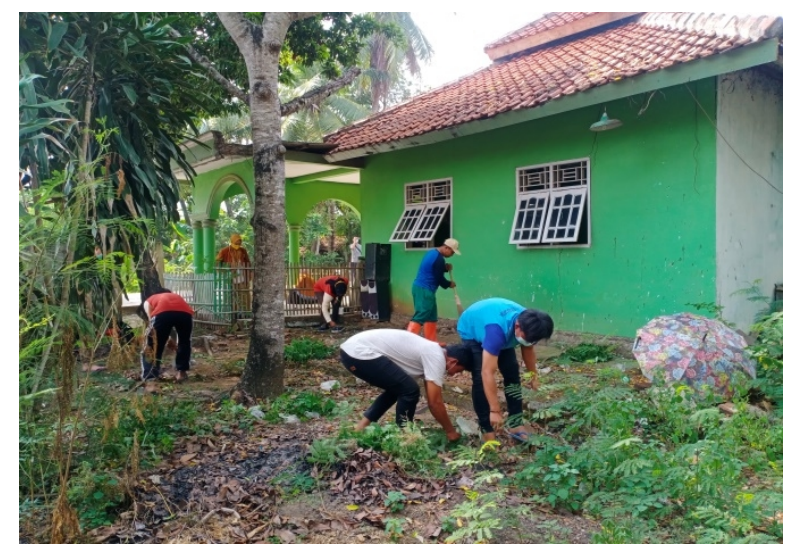

(b)

Gambar 4. Bakti sosial tempat Ibadah (a) mahasiswa memberikan alat kebersihan untuk musala warga (b) kegiatan kebersihan wujud kepedulian sosial

Menurut Asnawati, rumah Ibadah merupakan sarana keagamaan yang penting bagi pemeluk agama di suatu tempat. Selain sebagai simbol "keberadaan" pemeluk agama, rumah ibadah juga sebagai tempat penyiaran agama dan tempat melakukan ibadah. Artinya fungsi rumah ibadah di samping sebagai tempat peribadahan diharapkan dapat memberikan dorongan yang kuat dan terarah bagi jamaahnya, agar kehidupan spiritual keberagamaan bagi pemeluk agama tersebut menjadi lebih baik dan salah satu tempat ibadah yang dimaksud adalah masjid [9]. Oleh karena itu, dalam program KKN mahasiswa STIT Rakeyan Santang berkomitmen dengan ikut peduli memberikan alat kebersihan dan bakti sosial diharapkan dengan program ini dapat memberikan kenyamanan ibadah warga dan musala menjadi bersih dan sehat. 


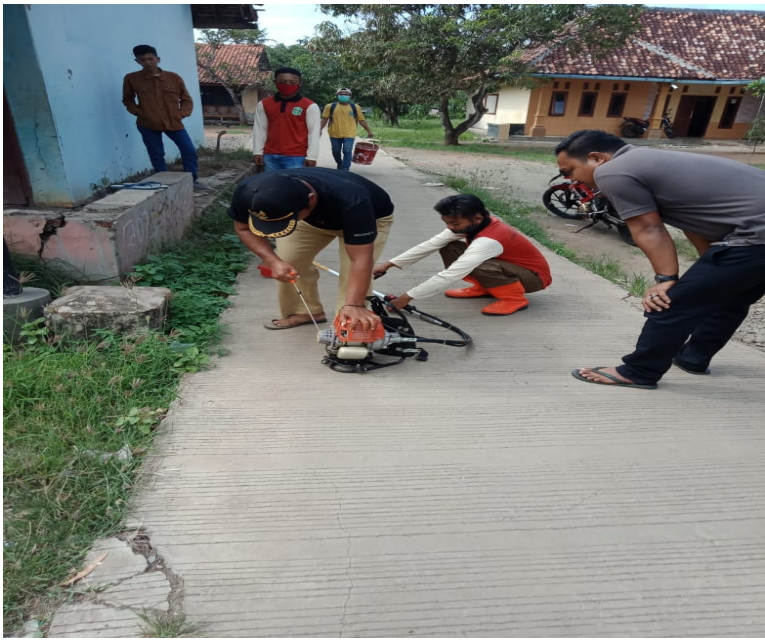

(a)

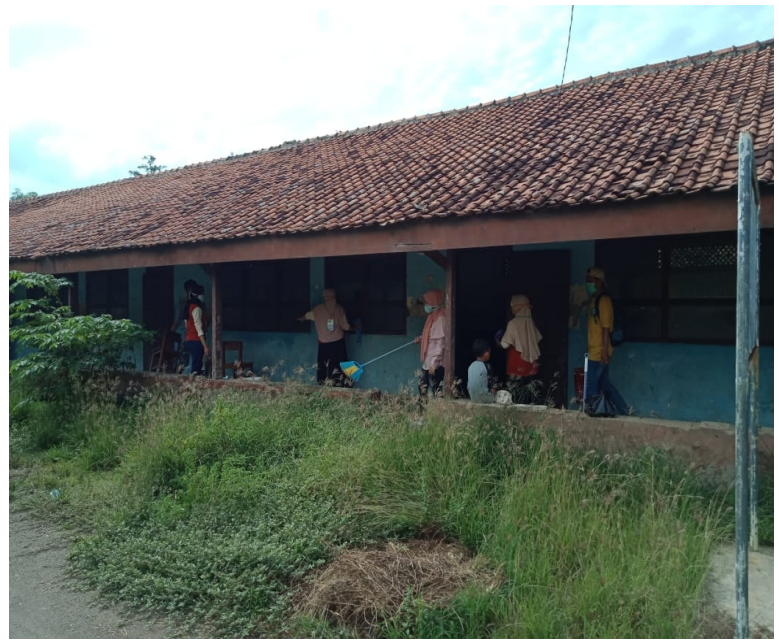

(b)

Gambar 5. Bakti sosial bersama warga (a) mahasiswa dan warga Desa bersama melakukan kebersihan umum (b) kepedulian terhadap sekolah wujud cinta tanah air

Pendidikan karakter adalah sebuah bantuan sosial agar individu itu dapat bertumbuh dalam menghayati kebebasannya dalam hidup bersama orang lain dalam dunia. Tujuan pendidikan karakter adalah untuk membentuk setiap pribadi menjadi insan yang berkeutamaan[10]. Dalam hal ini KKN Mahasiswa STIT Rakeyan Santang Karawang berupaya memberikan pendidikan karakter dengan mau melakukan bakti sosial dengan warga dan ikut peduli terhadap kebaradaan lembaga pendidikan sebagai wujud Tarbiyah yaitu pendidikan, pembinaan dalam mengembangankan ilmu pengetahuan dan kepedulian sosial sebagai anak bangsa yang Cinta Tanah Air.

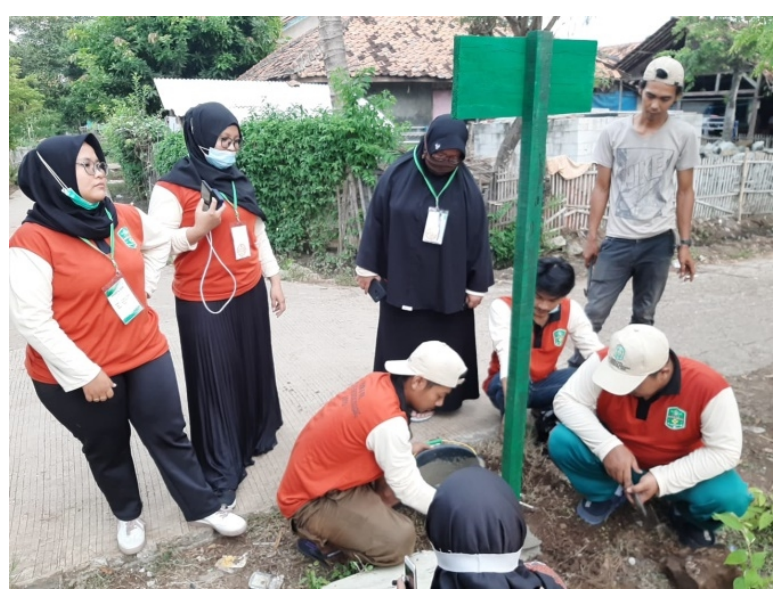

(a)

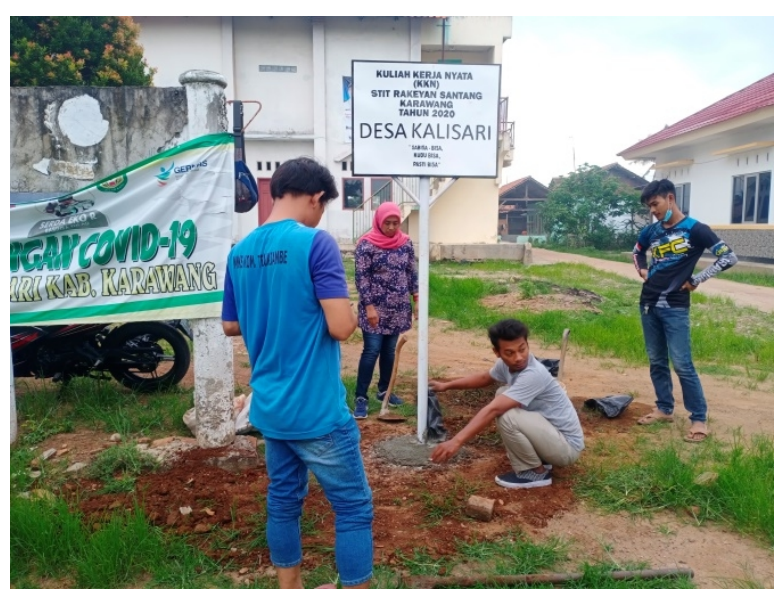

(b)

Gambar 6. Pemasangan plang Desa (a) mahasiswa peserta KKN memasangan plang batas desa penghubung (b) pemasangan plang Desa wujud bantuan mahasiswa dalam tata letak geografis

Batas wilayah merupakan suatu hal yang sangat penting guna untuk mengoptimalkan kewenangan suatu daerah. Oleh sebab itu, penentuan batas wilayah merupakan salah satu permasalahan di Indonesia sampai saat ini karena batas wilayah berhubungan beberapa faktor seperti politik dan kekayaan sumber daya alam pada wilayah tersebut. Batas wilayah mengalami permasalahan hingga batas antar desa yang saling tumpang tindih antara satu desa dengan desa yang lain. Batas wilayah desa yang sudah ditetapkan dengan baik akan memudahkan pemerintah desa dalam menjalankan kewenangan desa dalam melakukan 
penataan desa[11]. Dalam Permendagri 1 tahun 2017 penataan desa, pemrakarsa dalam penataan desa, masih minimnya daerah melakukan penataan kewenangan desa melalui peraturan kepala daerah. Kewenangan desa adalah terkait batas wilayah yang merupakan dasar untuk mengelola keruangan di desa serta menegakan kewenangan desa yang berimplikasi pada model pembangunan dan pemberdayaan di Desa. Desa harus memiliki batas wilayah dan kewenangan desa sehingga adanya kewenangan tanpa batas wilayah akan menyebabkan banyak permasalahan[12]. Oleh karena itu dalam melaksanakn program KKN mahasiswa agar jelasnya batas penghubung Desa dan arah petunjuk yaitu dengan membuat plang batas Desa. Hal ini membantu pemerintahan Desa agar penataan Desa menjadi terarah dan warga luarpun terbantu dalam memudahkan batas penghubung antar Desa Kalisari dan Desa lainnya.

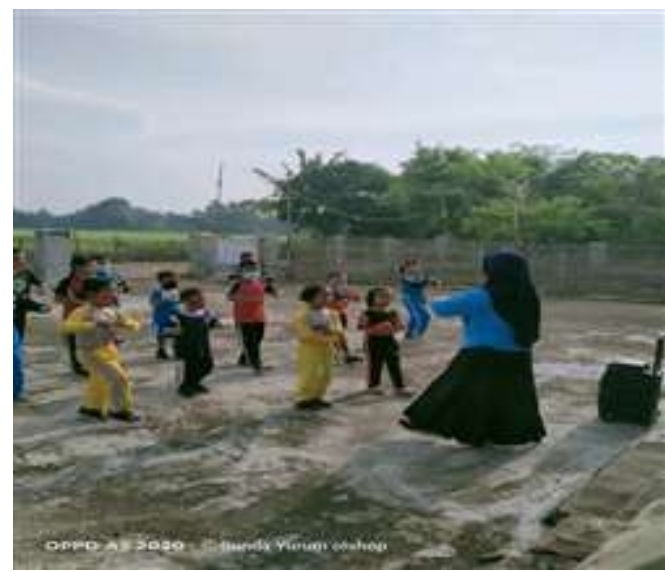

(a)

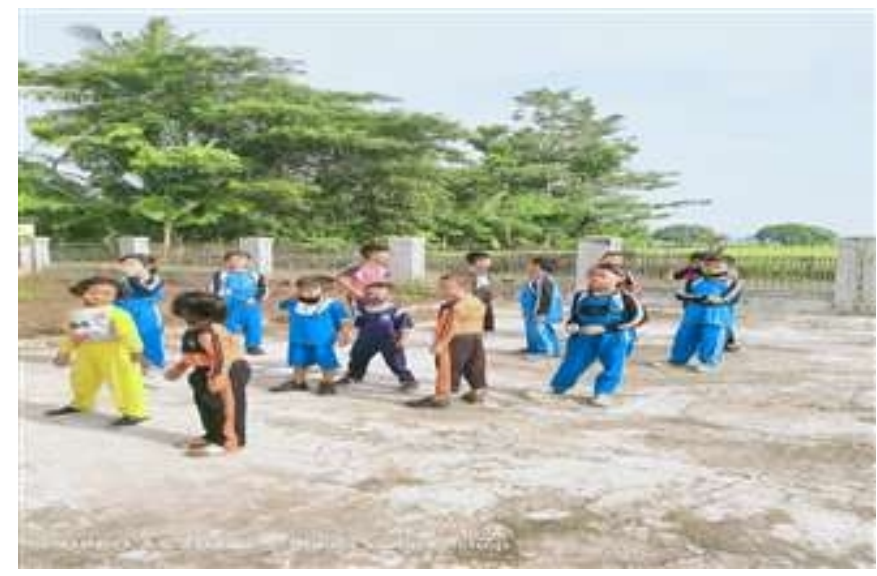

(b)

Gambar 7. Senam sehat Covid-19 (a) mahasiswa KKN STIT Rakeyan Santang memberikan edukasi tentang kebugaran tubuh (b) tubuh yang bugar akan terbebas dari segala bentuk virus

Senam adalah bentuk latihan tubuh yang disusun secara sistematis dengan tujuan untuk meningkatkan daya tahan, kekuatan, kelenturan, kelincahan, koordinasi, dan kontrol tubuh[13]. Kegiatan senam juga sebagai alat untuk mendorong pertumbuhan dan perkembangan jasmani, rohani, dan kesehatan terutama untuk anak[14]. Dengan demikian pada masa covid-19 ini pelaksanaan KKN mahasiswa dalam menjaga kestabilan tubuh warga dengan mengadakan senam sehat setiap minggunya. Sehingga diharapkan mampu memperkuat daya tahan tubuh sehingga terbebas dari segala bentuk virus maupun penyakit.

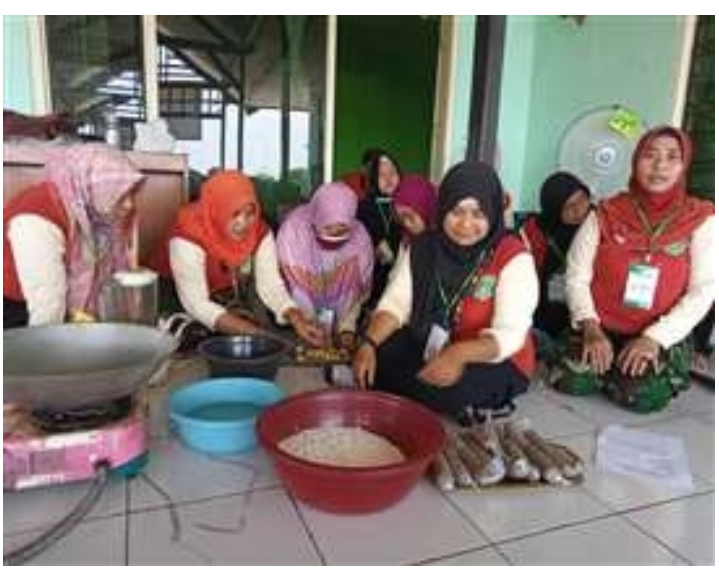

(a)

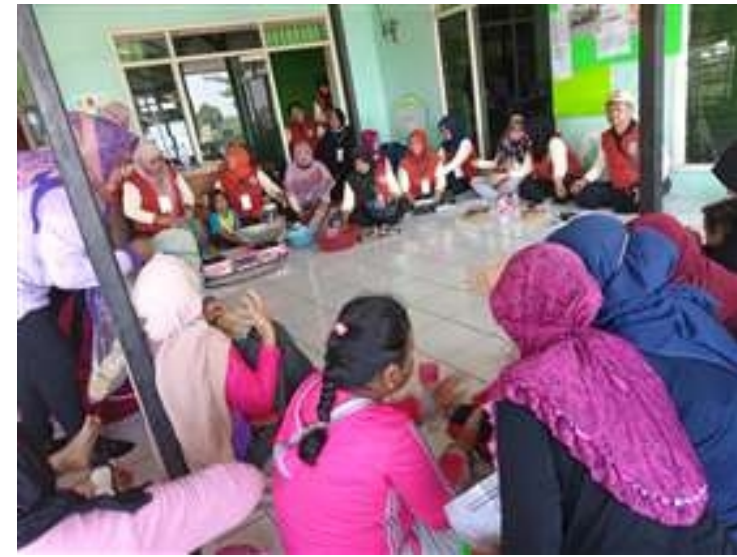

(b) 
Gambar 8. Ekonomi kreatif (a) mahasiswa memberikan edukasi usaha ekonomi sederhana (b) pembuatan kerupuk jengkol wujud pengembangan UMKM

Diketahui bahwa konsep ekonomi kreatif dengan mengedepankan sumber daya manusia yang memiliki ide dan pengetahuan untuk digunakan sebagai faktor utama dalam memproduksi barang dan jasa. Dengan kata lain bahwa ekonomi kreatif yang mulai berkembang ini mengedepankan kreativitas, pengetahuan, dan ide-ide yang dimiliki oleh seseorang sebagai aset dalam menjadikan perekonomian agar dapat bergerak lebih maju. Dengan konsep ini dapat terbukti bahwa mampu mengembangkan sektor perekonomian[7]. Dengan demikian kehadiran KKN mahasiswa STIT Rakeyan Santang mampu menguatkan perekonomian warga Desa Kalisari Karawang dengan ide-ide kreatif yaitu pembuatan kerupuk jengkol. Hal ini dapat dikembangkan mengingat pembuatan dan prosesnya tidak rumit dan mudah didapat bahan dasarnya. Sehingga dengan ekonomi kreatif ini dapat meningkatkan ekonomi warga sebagai wujud pergerakan ekonomi warga yang mandiri dan produktif.

\section{KESIMPULAN}

Berdasarkan hasil pelaksanaan pengabdian, maka beberapa kesimpulan dari kegiatan ini adalah: (a) program KKN Desa Kalisari sangat didukung oleh Pemerintahan baik Kabupaten maupun Desa karena membantu pemerintah dalam pemberdayaan masyarakat; (b) program KKN- Desa Kalisari menjadi sarana dalam memutus rantai Covid-19 dengan kegiatan-kegiatan edukasi sosial dalam pengabdian kepada masyarakat; dan (c) program KKN menjadi sarana untuk menggali potensi daerah yang belum dikelola dengan baik dan hasil dari pelaksanaan KKN mahasiswa STIT Rakeyan Santang Karawang yang telah dicapai adalah pengadaan dan pemberian alat kebersihan dan ibadah, kerja bakti sosial tempat (musala, madrasah, lapangan), pembuatan dan pemasangan plang batas desa, senam sehat edukasi covid-19, pembekelan usaha ekonomi kreatif, dan edukasi pencegahan covid-19. Sehingga kehadiran Kegiatan KKN STIT Rakeyan Santang Karawang ini dapat meningkatkan kesadaran dan kepedulian masyarakat Desa Kalisari akan pentingnya hidup bersosial kemasyarakatan, sehat, dinamis dan berkemajuan. Adapun saran dalam pelaksanaan program KKN mahasiswa di Desa Kalisari yaitu perlunya dukungan dari elemen masyarakat lainnya dalam pencapaian program KKN Desa Kalisari yang lebih komprehensif sehingga warga mampu mau berubah dan lebih peduli terhadap kesehatan, pengembangan ekonomi dan sosial kemasyarakatan.

Diharapkan pelaksanaan pengabdian masyarakat melalui KKN menjadi sumbangsih nyata baik secara moril dan spiritual dan tidak hanya bermanfaat khususnya bagi civitas akademik STIT Rakeyan Santang, melainkan untuk Desa Kalisari beserta masyarakatnya.

\section{UCAPAN TERIMA KASIH}

Penulis mengucapkan terima kasih kepada pihak-pihak yang telah memberi dukungan baik perizinan, maupun moril terhadap pengabdian ini.

1. Kepada Dinas Pemberdayaan Masyarakat Dan Desa Kabupaten Karawang yang telah mendukung program KKN STIT Rakeyan Santang

2. Kepada Kepala Desa Kalisari Kecamatan Telagasari Kabupaten Karawang Bapak. Komarudin, A.Md yang telah memberikan fasilitas bagi kegiatan KKN STIT Rakeyan Santang.

3. Kepada Ketua STIT Rakeyan Santang Karawang Bapak. Hendar, SE., S.AP., MH., M.Sc., MM yang memberikan arahan dan nasihat dalam terlaksananya program KKN-PPM.

4. LPPM STIT Rakeyan Santang.

5. Para Dosen Pendamping Lapangan (DPL)

6. Seluruh lapisan masyarakat Desa Kalisari Kecamatan Telagasari Kabupaten Karawang. 


\section{DAFTAR PUSTAKA}

[1] S. Wibawa, "Tridharma Perguruan Tinggi (Pendidikan Dan Pengabdian Kepada Masyarakat)," Disampaikan dalam Rapat Perenc. Pengawas. Proses Bisnis Perguru. Tinggi Negeri. Yogyakarta, vol. 29, pp. 1-15, 2017.

[2] U.-U. No, "tahun 2003 tentang sistem Pendidikan Nasional." 20AD.

[3] K. E. RISET, "UNIVERSITAS INDONESIA."

[4] K. S. N. RI, "KEPRES Nomor 7 Tahun 2020 Tentang GUGUS TUGAS PERCEPATAN PENANGANAN CORONA VIRUS/DISEASE 2019 (COVID-19)," 2020.

[5] B. Waluya, Sosiologi: Menyelami fenomena sosial di masyarakat. PT Grafindo Media Pratama, 2007.

[6] https://www.karawangkab.go.id/sites/default/files/PROFILEKECAMATANTELAGASARI., "No Title.".

[7] A. P. Sari et al., Ekonomi Kreatif. Yayasan Kita Menulis, 2020.

[8] O. Soemarwoto, "Ekologi lingkungan hidup dan pembangunan," 1991.

[9] V. A. Rachma, "Rancangan Sistem Informasi Website Online pada Sebuah Masjid (Tempat Ibadah)," 2020.

[10] N. A. Hani, "Upaya Penanaman Karakter Cinta Tanah Air di SD Negeri 2 Purbalingga Lor." Skripsi.

[11] N. Bashit, Y. Prasetyo, H. S. Firdaus, and F. J. Amarrohman, "Penetapan batas desa secara kartometrik menggunakan citra quickbird," J. Pasopati Pengabdi. Masy. dan Inov. Pengemb. Teknol., vol. 1, no. 1, 2019.

[12] P. M. D. N. Nomor, "tahun 2017 tentang Penataan Desa," Republik Indones., 1AD.

[13] A. Mahendra, "Senam," Yogyakarta FIK UNY, 2000.

[14] P. R. Ramadhani, "Upaya Meningkatkan Keterampilan Motorik Kasar Anak Kelompok B Melalui Senam Irama di TK ABA Sungapan Tirtorahayu Galur Kulon Progo," Univ. Negeri Yogyakarta, 2018. 